\title{
Effect of habitat complexity on predation success: re-evaluating the current paradigm in seagrass beds
}

\author{
Carly R. Canion ${ }^{1,2,3 *}$, Kenneth L. Heck Jr. ${ }^{1,2}$ \\ ${ }^{1}$ Department of Marine Sciences, University of South Alabama, Mobile, Alabama 36688, USA \\ ${ }^{2}$ Dauphin Island Sea Lab, 101 Bienville Boulevard, Dauphin Island, Alabama 36528, USA \\ ${ }^{3}$ Division of Marine Fisheries Management, Florida Fish and Wildlife Conservation Commission, Tallahassee, Florida 32301, USA
}

\begin{abstract}
The complex structure of seagrass beds provides increased protection for prey compared to unvegetated substrates. Additionally, most studies support the notion that predation intensity is negatively correlated with seagrass density. However, virtually every study to previously test this idea has used the same number of predators and prey across a gradient of seagrass density treatments. This design ignores another well-established fact: invertebrate and fish abundance increase with increasing seagrass density. Therefore, it makes sense to carry out predation experiments that increase the number of both predators and prey as seagrass density increases. Outdoor tank experiments ( 7 density treatments: 0 to 3000 leaves $\mathrm{m}^{-2}$ ) were carried out using artificial seagrass units modeled after turtlegrass Thalassia testudinum and field mesocosm experiments (4 density treatments: 0 to 3000 leaves $\mathrm{m}^{-2}$ ) in living T. testudinum in Big Lagoon (Florida, USA). In these experiments the absolute number of predators (the pinfish Lagodon rhomboides) and prey (grass shrimp Palaemonetes pugio) were increased with increasing seagrass density. Both experiments yielded similar results: the only significant difference in predation rate was between the unvegetated treatment and the seagrass treatments as a group. These results suggest that dense seagrass does not necessarily provide increased protection for prey organisms.
\end{abstract}

KEY WORDS: Habitat complexity $\cdot$ Predation $\cdot$ Seagrass

Resale or republication not permitted without written consent of the publisher

\section{INTRODUCTION}

The many effects of predation on the composition, abundance, and behavior of prey species are perhaps better understood in shallow coastal waters than anywhere else. In nearshore waters where predation is often intense (Orth et al. 1984, Clark et al. 2003), shelter provided by complex habitats such as seagrass meadows can dramatically reduce mortality from predation (see review by Heck \& Orth 2006). Because the leaves of seagrass provide an estimate of habitat structure that can readily be measured and manipulated, there is a large amount of literature on the role of seagrass in providing protection from predators for a variety of small finfish and shellfish (Stoner 1982, Gotceitas \& Colgan 1989, Harris et al. 2004).

In the earliest studies on the relationship between seagrass density and predation rate, Nelson (1979) found that the foraging efficiency of the pinfish Lagodon rhomboides and grass shrimp Palaemonetes pugio on the amphipod Melita appendiculata (Say) decreased with increasing density of eelgrass Zostera marina. Because predation success did not decrease linearly as seagrass density increased, Nelson (1979) proposed that a step function best described these results (Fig. 1), and subsequent studies supported this model as an appropriate description of the relationship between habitat complexity and predation rate (Heck \& Thoman 1981, Savino \& Stein 1982, Adams et al. 2004). An alternate model was put forth by Crowder \& Cooper (1982). They allowed bluegill Lepomis macrochirus to feed on invertebrates in ponds containing varying densities of freshwater macrophytes. Their results suggested that predation rates are maximized at intermediate habitat complexity (Fig. 1).

Recent studies have largely shown that, regardless of whether a threshold actually exists, increasing sea- 


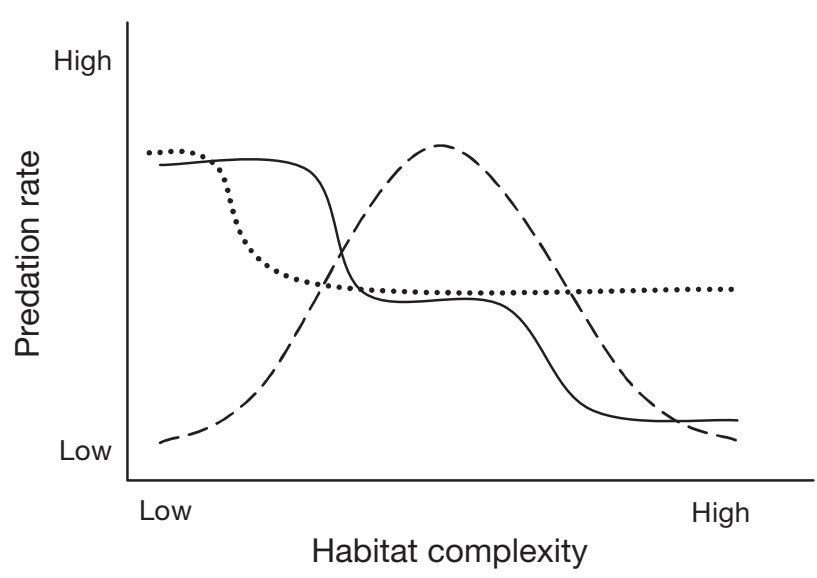

Fig. 1. Potential relationships between habitat complexity and predation rates (expressed as percentage of initial prey eaten or the probability of mortality). Solid line proposed by Nelson (1979); dashed line proposed by Crowder \& Cooper (1982).

Dotted line represents our predicted experimental results

grass density is negatively correlated with predator success (Nelson 1979, Heck \& Thoman 1981, Crowder \& Cooper 1982, Stoner 1982, Orth et al. 1984, Jordan et al. 1996, Hovel \& Lipcius 2001, Adams et al. 2004). One of the only known exceptions to this pattern is a study by James \& Heck (1994), in which the foraging ability of the seahorse Hippocampus erectus, an ambush predator unlike the active foragers used in prior studies, was not significantly affected by increasing seagrass density. Because so many studies have reported the positive effect of seagrass density on prey survival, the idea has reached the status of a paradigm and has not been frequently questioned.

However, it is also well understood that animal abundance and biomass, specifically of decapod crustaceans (Heck \& Orth 1980, Gore et al. 1981), gastropods, mussels, and crabs (Lee et al. 2001), as well as other epifaunal invertebrates (Stoner 1980, Attrill et al. 2000), and fish (Johnson \& Jennings 1998, Wyda et al. 2002) increases with increasing seagrass density. For example, Heck \& Orth (1980) found the abundance of Callinectes sapidus, Crangon septemspinosa, and Palaemonetes spp. to be positively correlated with Zostera marina biomass; leaf number of $Z$. japonica was also positively related to the abundance of invertebrates (Lee et al. 2001). In Chesapeake Bay, fish populations decreased when eelgrass beds began thinning, and sites that sustained high $Z$. marina density had significantly higher abundance, biomass, and species richness of fish assemblages (Wyda et al. 2002).

To accurately test the effect of seagrass density on predation rate, the fact that more fish and invertebrates occur in dense seagrass meadows (Heck \& Orth 1980, Orth et al. 1984, Edgar 1990, Jenkins et al. 1997,
Webster et al. 1998, Lee et al. 2001, Wyda et al. 2002) should be addressed in the design of experiments. However, a literature search has shown that the designs of all previous studies, except the recent study of Mattila et al. (2008), have held the number of predator and prey constant across all seagrass density treatments (Cooper \& Crowder 1979, Nelson 1979, Coen et al. 1981, Heck \& Thoman 1981, Savino \& Stein 1982, Main 1987, Ryer 1988, Nelson \& Bonsdorff 1990, Jordan et al. 1996, Macia et al. 2003). Increasing seagrass density without increasing the abundance of predators and prey can effectively create more protection for prey at high seagrass densities by lowering encounter rates between predators and prey; the result is likely to be reduced predation rates at high seagrass density because of decreased encounter rate, not because of seagrass density per se, while in low seagrass density, higher encounter rates should result in higher predation rates. Therefore, these prior experiments have actually tested both the effect of varying encounter rate and habitat structure on predator success.

In natural settings, the encounter rate should be fairly constant in all densities of seagrass. This is because, as noted above, the numbers of predators and prey increase with increasing seagrass density (Heck \& Orth 1980, Wyda et al. 2002). Empirical evidence of predator: prey ratios at varying levels of seagrass density does not exist, and in this study a constant ratio of predator: prey (1:10) was used in the outdoor tank experiments. While this ratio is an oversimplification of natural conditions, it serves to reduce the complexity of the analysis and interpretation of results. The number of predators and prey used in each seagrass density treatment were designed to closely mimic their natural abundance by consulting previously recorded observations in the Gulf of Mexico (Coen et al. 1981, Gore et al. 1981, Huh 1984, Heck et al. 2000, Spitzer et al. 2000). Because virtually all past predation studies in seagrass habitats have inaccurately reflected natural conditions, it seemed appropriate to re-evaluate the current paradigm that increasing seagrass density provides increasing refuge from predation.

In a recently published paper, Mattila et al. (2008) designed an experiment with a constant ratio of predator to prey that was used at 4 seagrass densities. The predator Lagodon rhomboides and the prey Palaemonetes pugio both utilize seagrass beds in increasing numbers as seagrass density increases (Adams et al. 2004), resulting in higher numbers of both species in denser seagrass. By slightly changing the experimental design, Mattila et al. (2008) results directly tested the current paradigm for seagrass density and predation. In contrast with almost all prior studies, Mattila et al. (2008) found that predation rate did not decrease with seagrass density. Instead, the only significant dif- 
ference occurred between the unvegetated treatment and all the seagrass density treatments. These results clearly suggest that it is necessary to re-evaluate the conventional wisdom concerning predation success and seagrass density.

The objective of this study was to further investigate the relationship between seagrass density and predation rate, using treatments that accurately reflected natural conditions. This study differs from nearly all previous studies by increasing both the number of predators and prey, instead of using a constant number of each, as seagrass density was increased. In particular, this study expands on the work of Mattila et al. (2008) because it includes a field test of the new experimental approach. The scope of the study is also enhanced by using a greater range of seagrass densities in the outdoor tank experiment.

\section{MATERIALS AND METHODS}

Experimental predator. The pinfish Lagodon rhomboides inhabits seagrass beds in the Gulf of Mexico and along the Atlantic coast of North America from Florida to Massachusetts, USA (Darcy 1985). In the southern part of its range, the pinfish is often one of the most abundant and important shallow water predators of small invertebrates (Nelson 1979, Stoner 1982, Jordan et al. 1996). In the Gulf of Mexico, pinfish recruit to seagrass beds in spring and are the dominant small fish until their fall migration offshore (Heck et al. 2000). The pinfish forages mostly inside seagrass beds (Main 1985, Spitzer et al. 2000), and it is likely that plant density affects its feeding habits and strategies (Nelson 1979, Jordan et al. 1996, Adams et al. 2004). Pinfish demonstrate an ontogenetic shift in feeding behavior, from primarily carnivory at small sizes to primarily herbivory at large sizes (Darcy 1985), which includes a middle omnivorous stage (26 to $120 \mathrm{~mm}$ ) when pinfish feed largely on shrimp, amphipods, and some algae (Livingston 1982). In this omnivorous stage, L. rhomboides is a visual predator that detects, pursues, and captures live prey such as caridean shrimp and amphipods (Stoner 1982, Main 1987). Main (1985) observed that pinfish actively search for prey, and strike whenever prey are encountered. All pinfish used in experiments measured between 65 to $85 \mathrm{~mm}$ total length.

Experimental prey. The caridean grass shrimp Palaemonetes pugio is among the most abundant decapods in coastal seagrass meadows (Welsh 1975, Posey \& Hines 1991). P. pugio is an important link in food chains of seagrass meadows, both as a prey item and a nutrient-recycling detritivore. Its main predators are small fishes (Schneider \& Mann 1991), and in the
Gulf of Mexico they are commonly consumed by Lagodon rhomboides (Gore et al. 1981, Main 1987). All grass shrimp used in experiments were between 15 to $25 \mathrm{~mm}$ in length, and gravid females were excluded.

Caridean shrimp exhibit avoidance behaviors that reflect the abundance and activity patterns of their predators. Palaemonetes pugio is active and abundant in the water column at night, when they are less susceptible to visual predators (Sogard \& Able 1994, Clark et al. 2003). Shrimp can also defend themselves in the presence of predators with different foraging strategies (Davis et al. 2003) by using leaves of seagrass as camouflage, reducing motion, and hiding behind leaves (Main 1985).

Collection and maintenance of experimental fish. All pinfish Lagodon rhomboides used in these experiments were captured using a $5.3 \mathrm{~m}$ otter trawl in seagrass beds in Big Lagoon (Florida). Pinfish were kept in a large holding tank and fed Palaemonetes pugio for up to $2 \mathrm{wk}$ before trials. The holding tank contained several artificial seagrass mats to reduce pinfish anxiety and aggression.

All grass shrimp used in experiments and for feeding pinfish in holding tanks were collected along marsh edges at Heron Bay (Alabama) using large dip nets. Grass shrimp were held in 10 gallon ( 37.8 l) tanks for up to $5 \mathrm{~d}$ before experiments. Both pinfish and shrimpholding tanks were filled with artificial seawater (Instant Ocean), and maintained at a salinity of 20 to 30 and a temperature of 20 to $25^{\circ} \mathrm{C}$.

Experimental design. To determine seagrass densities to use in the experiments, data from literature (Iverson \& Bittaker 1986, James \& Heck 1994, Mattila \& Heck 2003) and field observations from Big Lagoon (Florida), were used. The natural density range of Thalassia testudinum near Big Lagoon, 0 to 3000 leaves $\mathrm{m}^{-2}$, is reflected in the seagrass density treatments chosen.

The number of pinfish and shrimp was first determined for the lowest density treatment used (500 leaves $\mathrm{m}^{-2}$ in the outdoor tank experiment). The number of pinfish ( 3 ind $\mathrm{m}^{-2}$ ) in the lowest density treatment (500 leaves $\mathrm{m}^{-2}$ ) was determined from previously recorded local observations ( 0.14 to 4.57 ind. $\mathrm{m}^{-2}$ ) in the Gulf of Mexico (Heck et al. 2000, Spitzer et al. 2000). The number of shrimp used (30 ind $\mathrm{m}^{-2}$ ) in the lowest density was based on previous quantitative studies of shrimp densities (Coen et al. 1981, Gore et al. 1981). After determining the number of pinfish and shrimp in the lowest density treatment, the numbers of both were extrapolated with each increase in seagrass density. For example, in the treatment with 3000 leaves $\mathrm{m}^{-2}$ (6 times the lowest leaf density of 500 leaves $\mathrm{m}^{-2}$ ), both the predator and prey numbers were multiplied by 6 to obtain 18 predators and 180 shrimp. 
In the outdoor tank experiments, a constant ratio of predator: prey of 1:10 was used in each treatment (see Table 3). Although this constant ratio does not reflect the variation in predator and prey numbers that can occur in nature, it is based on a number of previously recorded densities of pinfish and grass shrimp from seagrass habitats in the northern Gulf of Mexico. Although the intent in this study was to use the 1:10 predator to prey ratio in the sand outdoor tank experiment as well as the field mesocosm experiments, constraints were imposed by the experimental setup. The minimum number of pinfish that could be used in a mesocosm was 2 (instead of 1), because pinfish do not forage efficiently alone (Jordan et al. 1996). Also, because the bottom surface area of the field mesocosms was small $\left(0.20 \mathrm{~m}^{2}\right)$, the number of pinfish included in each treatment had to be rounded to the nearest round number. These 2 aspects of the design meant that it was not possible to keep a constant 1:10 predator to prey ratio in these experiments. The actual ratios used in the field mesocosm experiments are shown in Table 1.

Field mesocosm experiment. Field experiments were conducted in Gulf Islands National Seashore, Big Lagoon (Florida; 30 $18^{\prime} 38.4^{\prime} \mathrm{N}, 87^{\circ} 22^{\prime} 17.5^{\prime} \mathrm{W}$ ) (Fig. 2). A large turtlegrass Thalassia testudinum bed that varied in shoot density and was surrounded by sandy sediment was used for the experiments. T. testudinum is an abundant seagrass in Gulf of Mexico polyhaline waters, and supports a wide variety of animal species (Stoner 1983). It has an extensive root and rhizome system, and its leaves have a high surface area compared to other co-occurring seagrass species (Stoner 1983).

Mesocosms were constructed of 44 gallon ( 166.6 l) Brute (Rubbermaid) trash containers (top diameter $\times$ height: $61 \times 93 \mathrm{~cm}$; bottom surface area $=0.2 \mathrm{~m}^{2}$ ). The bottoms were removed and $3(25 \times 30 \mathrm{~cm})$ rectangular holes were cut into the sides of the containers to allow water exchange. Large holes were also cut out of the

Table 1. Lagodon rhomboides and Palaemonetes pugio. Treatment levels for field mesocosm experiments. Number of predator and prey individuals are based on a mesocosm surface area of $0.20 \mathrm{~m}^{2}$

\begin{tabular}{|c|c|c|c|c|c|c|c|}
\hline Treatment & $\left(\right.$ no. $\left.\mathrm{m}^{-2}\right)$ & $\begin{array}{l}- \text { Leaves } \\
\left(\text { no. mesocosm }{ }^{-1}\right)\end{array}$ & $\overline{\left(\text { ind. } \mathrm{m}^{-2} \text { ) }\right.}$ & $\begin{array}{l}\text { Predators } \\
\quad \text { (ind. mesocosm }{ }^{-1} \text { ) }\end{array}$ & (ind. $\mathrm{m}^{-2}$ ) & $\begin{array}{l}\text { - Prey } \\
(\text { ind. mesocosm }\end{array}$ & $\begin{array}{l}\text { Predator: } \\
\text { prey ratio }\end{array}$ \\
\hline 1 & 0 & 0 & 2 & 2 & 20 & 4 & $1: 2$ \\
\hline 2 & 1000 & 200 & 6 & 2 & 60 & 12 & $1: 6$ \\
\hline 3 & 2000 & 400 & 12 & 3 & 120 & 24 & $1: 8$ \\
\hline 4 & 3000 & 600 & 18 & 4 & 180 & 36 & $1: 9$ \\
\hline
\end{tabular}

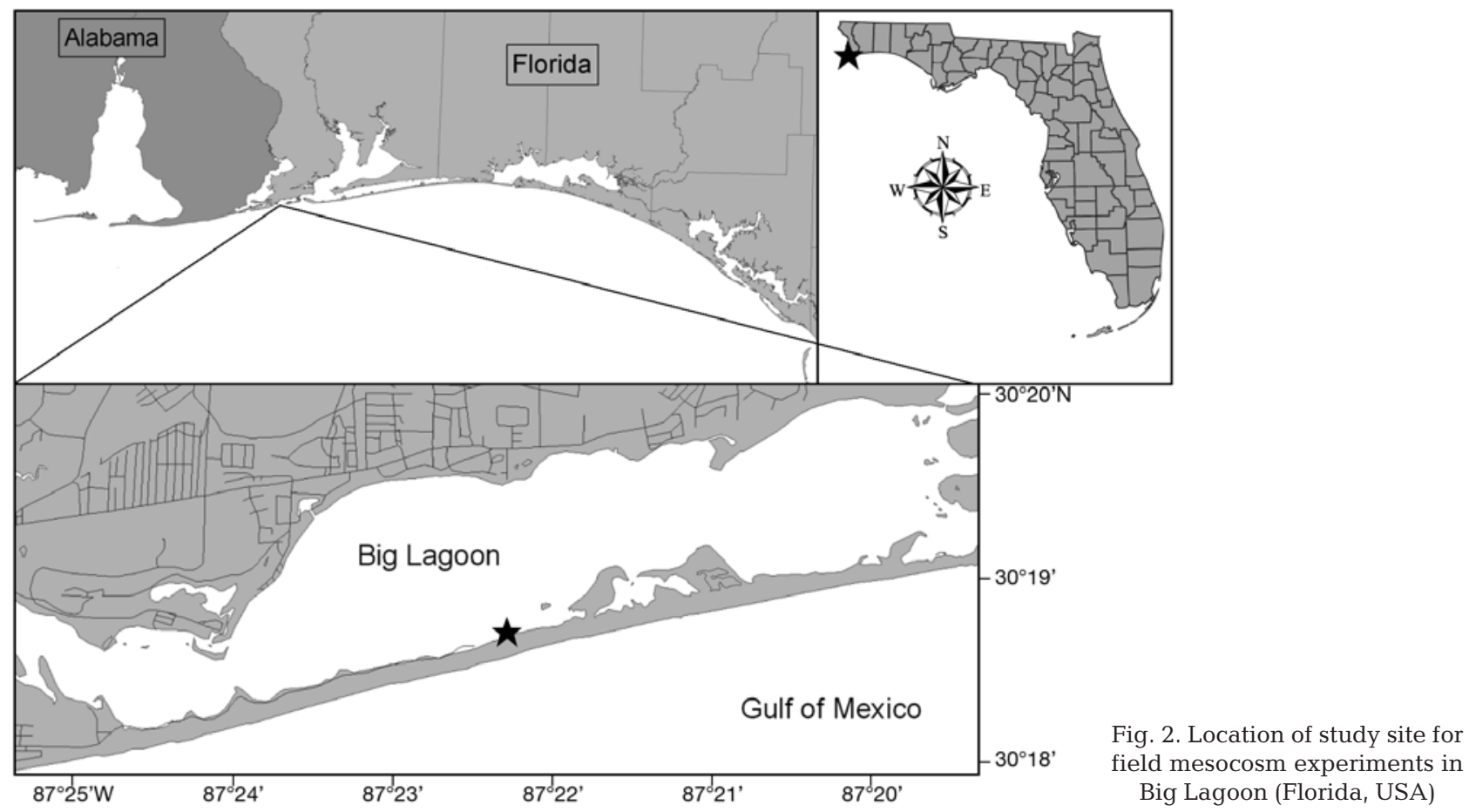


trash can lids, which acted as tops for the mesocosms. Vexar (Conwed Plastics) plastic mesh (2 mm) was melted onto all holes with a flame torch, and 4 PVC pipes were attached to the outside of the mesocosms to provide stability.

Field mesocosm experiments contained 4 treatments: sand and 3 seagrass densities. The approximate seagrass density for a treatment was located within the chosen seagrass bed, and seagrass leaves were counted and trimmed to match the number of leaves needed to create the treatment. The mesocosm was then pressed into the sediment surrounding the manipulated plot and secured with 4 long pieces of rebar that ran through the PVC. Guy-wires added extra stability, and were anchored in the sediment with short rebar. Extra care was taken to force the mesocosms deeply into the sediment so that neither predators nor prey could escape. The sand treatment was placed on unvegetated bottom adjacent to the seagrass bed, in approximately the same water depth.

When the mesocosms were in place, the existing organisms were removed by a suction sampling system similar to the one described by Orth \& van Montfrans (1987). Suction sampling has been shown to efficiently sample a high proportion of enclosed mobile macrofauna (Wilson et al. 1990). For example, Wilson et al. (1990) recovered $88 \%$ of marked juvenile blue crabs in unvegetated bottom, and $86 \%$ in eelgrass. The efficiency of the suction sampling gear was tested, and $100 \%$ of the 36 shrimp stocked in a mesocosm over sand were recovered.

Mesocosms were suction sampled for $1 \mathrm{~min}$ to clear enclosed macrofauna. The shrimp were added and allowed to acclimate for approximately $20 \mathrm{~min}$ before the pinfish (starved for $5 \mathrm{~d}$ ) were measured and added. The experiments ran for $6 \mathrm{~h}$. To conclude an experiment the lids were opened and the mesocosms were suction sampled as described above and dip-netted until 3 consecutive passes collected no further organisms. The mesh size of the suction sampling collecting bag was $<1 \mathrm{~mm}$, and small enough to retain grass shrimp. The suctioned material was stored in Ziploc bags for later processing. Temperature and salinity measurements were also taken with a YSI-85 (YSI) dissolved oxygen and conductivity instrument. The predation rate was determined by subtracting the number of shrimp that survived from the total added initially, divided by the initial input. Therefore, predation rate throughout this study is defined as the percentage of the initial prey number eaten over the experimental period.

The data were deemed normal after testing with a Ryan-Joiner Normality Test. A 1-way ANOVA was run with seagrass density as the factor and predation rate as the response variable. Six replicates were carried out; however, trials that did not have a $100 \%$ recapture rate of pinfish were excluded. The number of replicates remaining for each treatment is shown in Table 2.

Outdoor tank experiment. All experiments were conducted outdoors in 150 gallon (567.8 l) stock tanks (Rubbermaid $^{\mathrm{TM}}$ ), with a bottom surface area of $0.64 \mathrm{~m}^{2}$ (length $\times$ width $\times$ height; $116 \times 68 \times 64 \mathrm{~cm}$ ). The tanks were covered with a $10 \mathrm{~cm}$ thick layer of sieved sand, and were opaque, which minimized outside disturbance to the organisms (Jordan et al. 1996). The 7 tanks were arranged on a dock at the Dauphin Island Sea Lab in a flow-through system. Ambient seawater was pumped into and drained out through a standing pipe inside each tank.

To control seagrass density artificial seagrass units (ASUs) were used. These seagrass mimics have been used in many previous experiments, including those studying animal and epiphyte colonization rates (Pinckney \& Micheli 1998, Kenyon et al. 1999), structure preferences (Sogard \& Olla 1993), and species diversity and abundance patterns (Lee et al. 2001). ASUs can be used to overcome some of the problems associated with experimenting with real seagrass, such as difficulty in manipulating shoot height and density because of different growth rates (Bell \& Westoby 1986, Lee et al. 2001). To mimic turtlegrass Thalassia testudinum the ASUs were constructed of polypropylene ribbon (approximately $26 \mathrm{~cm}$ long and $7.5 \mathrm{~mm}$ wide) and tied haphazardly to $\operatorname{Vexar}{ }^{\mathrm{TM}} \operatorname{mesh}\left(1 \mathrm{~cm}^{2}\right)$.

Table 2. Lagodon rhomboides. Percent recapture of pinfish in each trial of field mesocosm experiment in Perdido Bay (Florida, USA). Only trials that had a $100 \%$ recapture rate were used in the analysis

\begin{tabular}{|c|c|c|c|c|c|c|c|c|}
\hline \multirow{2}{*}{ Treatment } & \multirow{2}{*}{$\begin{array}{l}\text { Pinfish caged } \\
\text { (n) }\end{array}$} & \multicolumn{6}{|c|}{ Pinfish recaptured $(\%)$} & \multirow{2}{*}{$\begin{array}{l}\text { Sample size } \\
\text { (n) }\end{array}$} \\
\hline & & Trial 1 & Trial 2 & Trial 3 & Trial 4 & Trial 5 & Trial 6 & \\
\hline Sand & 2 & 50 & $100^{\mathrm{a}}$ & 50 & 100 & 100 & 100 & 3 \\
\hline Low density & 2 & 50 & 50 & 50 & 100 & 100 & 100 & 3 \\
\hline Medium density & 3 & 100 & 100 & 66 & 100 & 100 & 100 & 5 \\
\hline High density & 4 & 100 & 100 & 100 & 100 & 100 & 100 & 6 \\
\hline
\end{tabular}


The tanks were always filled about $25 \mathrm{~cm}$ above the tips of artificial seagrass leaves, which prevented shrimp from jumping out of the water when attacked by predators.

Seagrass density and number of predators and prey used in each treatment level were determined as described above ('Experimental design'; Table 3). Experiments were conducted with 7 different treatments: bare sand with Vexar mesh (as a control for mesh presence), and 6 different seagrass densities (Table 3), each naturally present in Big Lagoon, the location of field mesocosm experiments.

The treatment assigned to each tank was randomized and changed with each group of experiments. The Vexar mesh of the ASU was buried in the sand bottom, tanks were filled the afternoon before the experiment, and flow was minimized overnight to reduce turbidity. To begin an experiment shrimp were counted and added to each tank. While shrimp acclimated, a YSI-85 ${ }^{\mathrm{TM}}$ was used to measure temperature, salinity, and dissolved oxygen. After approximately $20 \mathrm{~min}$, pinfish (starved for $5 \mathrm{~d}$ ) were measured and added in appropriate counts to each tank (Table 3), and the experiment began. All these experiments were conducted between 08:00 and 17:00 h, when pinfish actively feed (Darcy 1985).

Experiments ran for $6 \mathrm{~h}$, after which the abiotic characteristics were measured again, flow was turned off, and ASUs were removed from each tank. Mesh bags were attached with Velcro to the drain pipe of each tank, a rubber drain plug was removed and, as tanks emptied, shrimp and fish were retained in the attached mesh bag. Once the tanks had drained, the contents of the mesh bag were placed into a labeled Ziploc bag, which was frozen until subsequent processing. No fish or shrimp were re-used in any experiments.

Ten replicates were carried out, and predation rate was determined as described for the field mesocosm experiments. All data were deemed normal after testing with a Ryan-Joiner Normality Test. A 2-way ANOVA was run with seagrass density and day as factors and predation rate as the response variable. Day was included as a randomized block factor.

\section{RESULTS}

\section{Field mesocosm experiment}

Predation losses ranged from 27 to $83 \%$ among the 4 seagrass density treatments. The predation rate of pinfish on grass shrimp differed significantly among the 4 grass density treatments (1-way ANOVA $F_{3,13}=6.84$, $\mathrm{p}<0.005)$. The highest predation rate was in the sand treatment (Fig. 3), which was significantly different (Tukey Simultaneous Test, $\mathrm{p}<0.05$ ) from all 3 seagrass treatments. However, the 3 seagrass density treatments did not significantly differ from each other (Fig. 3). The temperature ranged from 30.2 to $33.7^{\circ} \mathrm{C}$ and the salinity ranged from 28.1 to 29.1 during the experiments.

\section{Outdoor tank experiment}

Predation losses ranged from 30 to $57 \%$ among the 7 seagrass density treatments. The predation rate of pinfish on grass shrimp differed significantly among the 7 grass density treatments (2-way ANOVA; $F_{6,69}=$ 2.57, $\mathrm{p}=0.029, \mathrm{n}=7$ ). The highest predation rate was in the sand treatment; however, it was only significantly different from the 500 leaves $\mathrm{m}^{-2}$ treatment (Tukey Simultaneous Test, p < 0.05) (Fig. 4a). The other factor in the model, day, was also significant (2-way ANOVA; $F_{9,69}=5.56, \mathrm{p}<0.001, \mathrm{n}=10$ ), because predation rates were lower on the last $3 \mathrm{~d}$ than on previous days, as Fig. 4b shows. The temperature ranged from 11.1 to $26.3^{\circ} \mathrm{C}$ and the salinity ranged from 21.0 to 28.2 during the experiments.

\section{DISCUSSION}

The results of the field study show that seagrass leaves provide greater protection for prey than unvegetated bottoms, as expected (see meta-analysis by Heck et al. 2003, and review by Bostrom et al. 2006),

Table 3. Lagodon rhomboides and the prey Palaemonetes pugio. Treatment levels for outdoor tank experiments. Number of predator and prey individuals are based on a tank surface area of $0.64 \mathrm{~m}^{2}$

\begin{tabular}{|c|c|c|c|c|c|c|c|}
\hline \multirow{2}{*}{ Treatment } & \multirow{2}{*}{$\left(\right.$ no. $\left.\mathrm{m}^{-2}\right)$} & \multirow{2}{*}{$\begin{array}{l}\text { Leaves } \\
\qquad\left(\text { no. } \operatorname{tank}^{-1}\right)\end{array}$} & \multirow{2}{*}{\multicolumn{2}{|c|}{$\begin{array}{l}\left.\text { (ind. } \mathrm{m}^{-2}\right) \\
\text { Predators } \\
\left.\text { (ind. } \operatorname{tank}^{-1}\right)\end{array}$}} & \multirow[b]{2}{*}{ (ind. $\mathrm{m}^{-2}$ ) } & \multirow{2}{*}{$\begin{array}{l}\text { Prey } \\
\quad \text { (ind. } \operatorname{tank}^{-1} \text { ) }\end{array}$} & \multirow{2}{*}{$\begin{array}{l}\text { Predator: } \\
\text { prey ratio }\end{array}$} \\
\hline & & & & & & & \\
\hline 1 & 0 & 0 & 2 & 2 & 20 & 13 & $1: 6.5$ \\
\hline 2 & 500 & 315 & 3 & 2 & 30 & 20 & $1: 10$ \\
\hline 3 & 1000 & 630 & 6 & 4 & 60 & 39 & $1: 10$ \\
\hline 4 & 1500 & 945 & 9 & 6 & 90 & 58 & $1: 10$ \\
\hline 5 & 2000 & 1260 & 12 & 8 & 120 & 77 & $1: 10$ \\
\hline 6 & 1500 & 1575 & 15 & 10 & 150 & 96 & $1: 10$ \\
\hline 7 & 3000 & 1890 & 18 & 12 & 180 & 116 & $1: 10$ \\
\hline
\end{tabular}




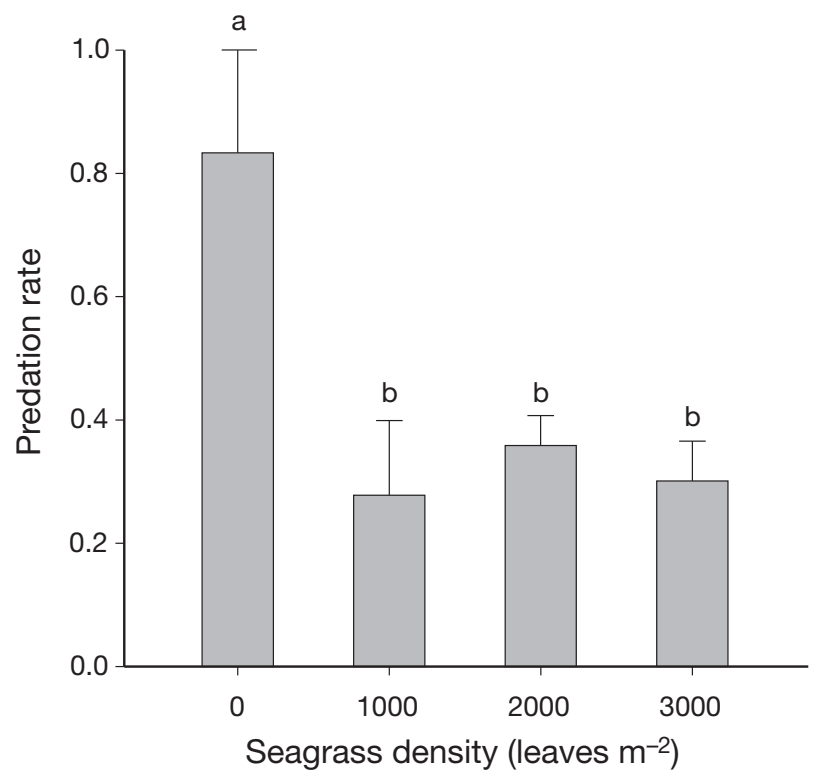

Fig. 3. Lagodon rhomboides and Palaemonetes pugio. Predation rate (mean $\pm \mathrm{SE}$ ) of pinfish on grass shrimp in field mesocosm experiments. The predation rate is the percentage of the initial prey number eaten over the experimental period. Treatments with different letters resulted in significant differences $(1$-way ANOVA, $\mathrm{p}<0.005)$

particularly when Lagodon rhomboides is the predator (Coen et al. 1981, Minello 1993). These results are consistent with those from prior studies. In contrast to results of past studies however, increased seagrass density did not decrease predation rates in either the field mesocosm or outdoor tank experiments. In the field mesocosm experiment, grass shrimp survival was not different among seagrass density treatments. This is inconsistent with the paradigm that dense seagrass protects prey from predation more effectively than sparse vegetation (Nelson 1979, Heck \& Thoman 1981, Crowder \& Cooper 1982, Savino \& Stein 1982, Stoner 1982, Orth et al. 1984, Jordan et al. 1996, Hovel \& Lipcius 2001, Adams et al. 2004). In particular, results presented here differ from others in showing that predatory abilities of $L$. rhomboides do not decrease with higher seagrass complexity when predator and prey densities remain constant (Nelson 1979, Coen et al. 1981, Stoner 1982).

Our results agree with Mattila et al. (2008), where the new perspective of the relationship between seagrass density and predation success was first introduced. Mattila et al. (2008) found no significant difference in survival of grass shrimp between any of the seagrass density treatments, and they concluded that dense seagrass does not always provide more protection for prey organisms. The test of the new experimental methods was extended by using a wider range
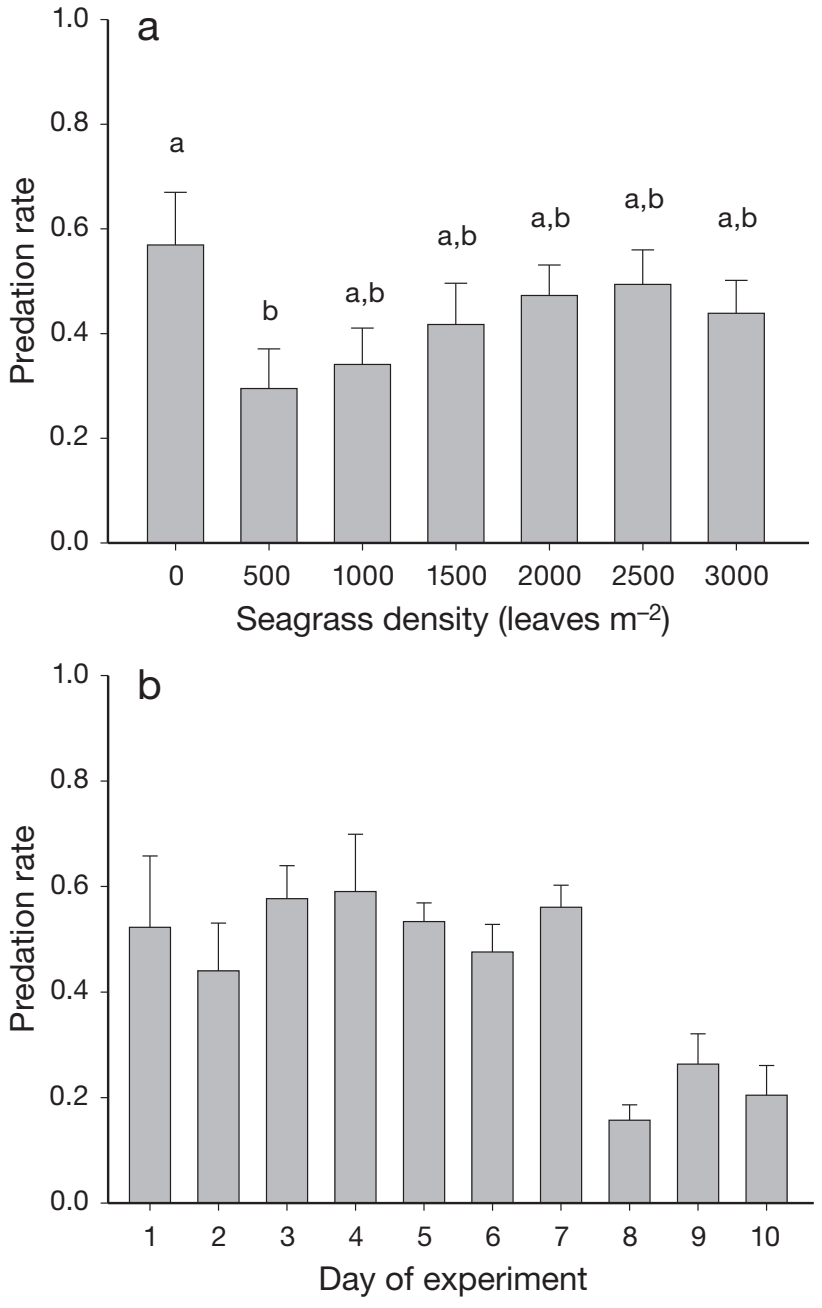

Fig. 4. Lagodon rhomboides and Palaemonetes pugio. (a) Predation rate (mean \pm SE) of pinfish on grass shrimp in outdoor tank experiments. The predation rate is the percentage of the initial prey number eaten over the experimental period. Treatments with different letters resulted in significant differences (2-way ANOVA, $\mathrm{p}<0.05)$. (b) Predation rate (mean of $\pm \mathrm{SE}$ ) on each day of experimentation in outdoor tank

of seagrass densities and a field experiment. Results in both the field mesocosm and outdoor tank experiments mirrored those of Mattila et al. (2008): varying levels of seagrass density provided similar protection for prey. The fact that these studies have very similar results should provide more confidence in the new theory.

One alternative driving force for the results of our study is that pinfish became satiated during some of the trials and stopped eating the shrimp. If pinfish are satiated by eating a lower number of shrimp than they were exposed to in the experimental treatments, the results would not necessarily have been affected by habitat complexity. To address this, the similar study of Mattila et al. (2008) can be examined. In that experi- 
ment there were 2 pinfish and 20 shrimp in the sand treatment. In the $4 \mathrm{~h}$ experiments, the mean predation rate of the pinfish on the shrimp was approximately $70 \%$. This means that about 14 shrimp were eaten, or about 7 shrimp per pinfish. Extrapolating the estimate given by Mattila et al. (2008) of 7 shrimp consumed per fish in $4 \mathrm{~h}$, the result is that one pinfish could eat approximately 10.5 shrimp in $6 \mathrm{~h}$, the trial time in this study. In none of the treatments in this study was the number of shrimp consumed per pinfish greater than 10.5, indicating that pinfish in these experiments were unlikely to have eaten enough shrimp to have become satiated.

Although the results generally support the hypothesis that increasing seagrass density does not decrease predator success, one aspect of the outdoor tank experiment results was unexpected: the lower than anticipated predation rate in the sand treatment. Because there were no visual barriers in sand, the grass shrimp consumption was expected to approach $100 \%$; instead, the fish consumed only $57 \%$ of the shrimp. In the field, however, Lagodon rhomboides consumed $83 \%$ of the shrimp in the sand treatment, much closer to expected values.

Jordan et al. (1996) found that habitat choice of Lagodon rhomboides was mediated by the presence of larger predators; similarly, pinfish growth was reduced in the presence of a predator by a reduction in the amount of time spent feeding (Harter \& Heck 2006). In these field mesocosm experiments, the mesocosms used were opaque except for mesh windows and were covered with a mesh lid. Therefore, predation risk was virtually non-existent for $L$. rhomboides in the field. However, the tanks in the outdoor experiments were not covered and predatory birds, such as blue herons, seagulls, and pelicans, were present in the area. It is possible that pinfish restricted their foraging in the outdoor tank sand treatments because they were unprotected from avian predators (Jordan et al. 1996), while fish in the field mesocosms did not experience the same threat because all predators were excluded. In addition, the outdoor tanks were situated on the dock of a research vessel, and people periodically walked by during the trials. When approaching the tanks at the end of a trial, the pinfish would scatter to the sides of the tank. It is possible that the periodic presence of people near the tanks during the experiment caused the pinfish to change their feeding activities. Reduced feeding time could have led to lower predation overall than seen in the field mesocosm results.

Although laboratory studies can be highly controlled and allow examination of a single factor, their results are, arguably, unable to be strictly applied to natural conditions. The field mesocosm experiments here increased realism, although caged environments are still simplified compared to natural conditions. One potentially important factor that was necessarily excluded from these field mesocosm experiments was the threat from predators of pinfish. As noted above, pinfish are less active and reduce feeding time when predators are present (Jordan et al. 1996, Harter \& Heck 2006). Studies have examined predation rates in the presence and absence of a higher order predator in seagrass habitat (Johnson \& Heck 2006), but no studies have examined this effect over a range of seagrass densities. Expected results of such a study would depend on the abundance of the higher order predators at different seagrass densities. If the higher order predator occurred in increased abundance with increasing seagrass density, predicted predation rates on its prey (such as pinfish) would be similar to those found in the results presented here on grass shrimp; that is, there would be decreased predation rates on the prey in each seagrass density. Studies could be done with the experimental design used here, plus a higher order predator in each treatment, to determine how predation rates of pinfish on shrimp are affected by predator presence in varying seagrass densities.

This study has implications for the habitat choice of both predators and prey. Past studies examining the effect of seagrass density on predation success attempted to determine optimal habitats for prey based on prey survival. Crowder \& Cooper (1982) reported that intermediate vegetation density provided optimal foraging value for prey because of the increased protection it provided, while most other studies reported dense seagrass as optimal habitat for prey because of its enhanced protection value (Coen et al. 1981, Stoner 1982, Orth et al. 1984, Nelson \& Bonsdorff 1990).

The results of these experiments do not lend themselves to the same interpretation as past studies. All densities of seagrass offered similar amounts of protection for prey and food for predators. Additionally, in the field mesocosms, the sand treatment was only significantly different from the lowest seagrass treatment. These results suggest that all densities of seagrass can be considered high quality habitat for prey organisms like grass shrimp. For predators, a trade-off exists between higher predation success in unvegetated bottom areas, and greater food resources in seagrass. Lagodon rhomboides used in this experiment also have their own predators, and seagrass offers an additional benefit as protection from them.

The meta-analysis performed by Heck et al. (2003) found no significant difference between the protection provided by seagrass (and other structurally complex habitats such as salt marshes and oyster reefs) for invertebrates and for juvenile fish. This meta-analysis included studies in both tropical and temperate regions, and Heck et al. (2003) hypothesized that in- 
creased survival in seagrass may be due to the presence of structure itself, rather than an inherent property of seagrass. The results presented here are similar and indicate that structure, regardless of density, enhances survival of prey. Aquatic structures, such as salt marsh plants, should be tested with the design described here.

The predator, Lagodon rhomboides, used in our study is an actively foraging predator; the majority of research conducted on the effect of seagrass structure on predator effectiveness has used similar search and pursuit foragers, as opposed to ambush predators (Flynn \& Ritz 1999). Coen et al. (1981) suggested that the concept of 'refuge' for prey in seagrass structure is dependent on predator strategy. Subsequent research showed that while foraging predators are usually visually inhibited by dense seagrass, ambush predators appear to use dense seagrass as camouflage, making them either positively affected or unaffected by a density increase (James \& Heck 1994, Flynn \& Ritz 1999). So while it seems likely that our results will be similar for other foraging predators, further testing is needed with ambush predators.

In conclusion, the results of this study add to our understanding of the role of habitat structure in coastal waters. Specifically, the results contradict those of a large number of previous studies and serve as a caution about accepting prior generalizations about habitat value. The manner in which varying habitat complexity provides protection for prey should be re-examined with new designs that closely mimic nature, which the authors believe will lead to a more precise understanding of the role of habitat complexity in seagrass meadows and other structurally complex habitats.

Acknowledgements. We thank Dr. S. Powers and Dr. S. Bell for advice that greatly improved this study. We also thank M. Johnson, L. Baggett, B. Furman, D. Booth, A. Canion, K. McKay, R. Gutierrez, D. Byron, C. Davis, R. Shiplett, M. Kent, M. Finnegan, C. Harris, D. Begert, E. Millstien, J. Blaine, S. Williams, E. Miller, and C. Gustafsson for help with field mesocosm and outdoor tank experiments. Financial support was provided by the Dauphin Island Sea Lab (DISL) and the Alabama Center for Estuarine Studies (ACES) at the University of South Alabama.

\section{LITERATURE CITED}

Adams AJ, Locascio JV, Robbins BD (2004) Microhabitat use by a post-settlement stage estuarine fish: evidence from relative abundance and predation among habitats. J Exp Mar Biol Ecol 299:17-33

Attrill MJ, Strong JA, Rowden AA (2000) Are macroinvertebrate communities influenced by seagrass structural complexity? Ecography 23:114-121

Bell JD, Westoby M (1986) Variation in seagrass height and density over a wide spatial scale: effects on common fish and decapods. J Exp Mar Biol Ecol 104:275-295

Bostrom C, Jackson EL, Simenstad CA (2006) Seagrass landscapes and their effects on associated fauna: a review. Estuar Coast Shelf Sci 68:383-403

Clark KL, Ruiz GM, Hines AH (2003) Diel variation in predator abundance, predation risk and prey distribution in shallow-water estuarine habitats. J Exp Mar Biol Ecol 287: $37-55$

Coen LD, Heck KL Jr, Abele LG (1981) Experiments on competition and predation among shrimps of seagrass meadows. Ecology 62:1484-1493

Cooper WE, Crowder LB (1979) Patterns of predation in simple and complex environments. In: Stroud RH, Clepper H (ed) Predator-prey systems in fisheries management. Sport Fishing Institute, Washington, DC, p 257-267

Crowder LB, Cooper WE (1982) Habitat structural complexity and the interaction between bluegills and their prey. Ecology 63:1802-1813

Darcy GH (1985) Synopsis of biological data on the pinfish, Lagodon rhomboides (Pisces: Sparidae). NOAA Tech Rep NMFS 23:1-32

> Davis JLD, Metcalfe WJ, Hines AH (2003) Implications of a fluctuating fish predator guild on behavior, distribution, and abundance of a shared prey species: the grass shrimp Palaemonetes pugio. J Exp Mar Biol Ecol 293:23-40

- Edgar GJ (1990) The influence of plant structure on the species richness, biomass and secondary production of macrofaunal assemblages associated with Western Australian seagrass beds. J Exp Mar Biol Ecol 137:215-240

- Flynn AJ, Ritz DA (1999) Effect of habitat complexity and predatory style on the capture success of fish feeding on aggregated prey. J Mar Biol Assoc UK 79:487-494

Gore RH, Gallaher EE, Scotto LE, Wilson KA (1981) Studies on decapod Crustacea from the Indian River region of Florida. II. Community composition, structure, biomass and speciesareal relationships of seagrass and drift algae-associated macrocrustaceans. Estuar Coast Shelf Sci 12:485-508

Gotceitas V, Colgan P (1989) Predator foraging success and habitat complexity: quantitative test of the threshold hypothesis. Oecologia 80:158-166

Harris LA, Buckley B, Nixon SW, Allen BT (2004) Experimental studies of predation by bluefish Pomatomus saltatrix in varying densities of seagrass and macroalgae. Mar Ecol Prog Ser 281:233-239

Harter SL, Heck KL Jr (2006) Growth rates of juvenile pinfish (Lagodon rhomboides): effects of habitat and predation risk. Estuaries Coasts 29:318-327

Heck KL Jr, Orth RJ (1980) Structural components of eelgrass (Zostera marina) meadows in the lower Chesapeake Bay - decapod Crustacea. Estuaries 3:289-295

Heck KLJ, Orth RJ (2006) Predation in seagrass beds. In: Larkum AWD, Orth RJ, Duarte CM (eds) Seagrasses: biology, ecology, and conservation. Springer, Dordrecht

$>$ Heck KL Jr, Thoman TA (1981) Experiments on predator-prey interactions in vegetated aquatic habitats. J Exp Mar Biol Ecol 53:125-134

Heck KL Jr, Pennock JR, Valentine JF, Coen LD, Sklenar SA (2000) Effects of nutrient enrichment and small predator density on seagrass ecosystems: an experimental assessment. Limnol Oceanogr 45:1041-1057

- Heck KL Jr, Hays G, Orth RJ (2003) Critical evaluation of the nursery role hypothesis for seagrass meadows. Mar Ecol Prog Ser 253:123-136

Hovel KA, Lipcius RN (2001) Habitat fragmentation in a seagrass landscape: patch size and complexity control blue crab survival. Ecology 82:1814-1829 
Huh SH (1984) Seasonal variations in populations of small fishes concentrated in shoalgrass and turtlegrass meadows. J Oceanol Soc Korea 19:44-55

Iverson RL, Bittaker HF (1986) Seagrass distribution and abundance in eastern Gulf of Mexico coastal waters. Estuar Coast Shelf Sci 22:577-602

> James PL, Heck KL Jr (1994) The effects of habitat complexity and light intensity on ambush predation within a simulated seagrass habitat. J Exp Mar Biol Ecol 176:187-200

Jenkins GP, May HMA, Wheatley MJ, Holloway MG (1997) Comparison of fish assemblages associated with seagrass and adjacent unvegetated habitats of Port Phillip Bay and Corner Inlet, Victoria, Australia, with emphasis on commercial species. Estuar Coast Shelf Sci 44:569-588

Johnson MW, Heck KL Jr (2006) Seagrass patch characteristics alter direct and indirect interactions in a tritrophic estuarine food web. Estuaries Coasts 29:499-510

Johnson BL, Jennings CA (1998) Habitat associations of small fishes around islands in the upper Mississippi River. N Am J Fish Manag 18:327-336

> Jordan F, Bartolini M, Nelson C, Patterson PE, Soulen HL (1997) Risk of predation affects habitat selection by the pinfish Lagodon rhomboides (Linnaeus). J Exp Mar Biol Ecol 208:45-56

Kenyon RA, Haywood MDE, Heales DS, Loneragan NR, Pendrey RC, Vance DJ (1999) Abundance of fish and crustacean postlarvae on portable artificial seagrass units: daily sampling provides quantitative estimates of the settlement of new recruits. J Exp Mar Biol Ecol 232:197-216

Lee SY, Fong CW, Wu RSS (2001) The effects of seagrass (Zostera japonica) canopy structure on associated fauna: a study using artificial seagrass units and sampling of natural beds. J Exp Mar Biol Ecol 259:23-50

Livingston RJ (1982) Trophic organization of fishes in a coastal seagrass system. Mar Ecol Prog Ser 7:1-12

Macia A, Abrantes KG, Paula J (2003) Thorn fish Terapon jarbua (Forskål) predation on juvenile white shrimp Penaeus indicus H. Milne Edwards and brown shrimp Metapenaeus monoceros (Fabricius): the effect of turbidity, prey density, substrate type and pneumatophore density. J Exp Mar Biol Ecol 291:29-56

Main KL (1985) The influence of prey identity and size on selection of prey by two marine fishes. J Exp Mar Biol Ecol 88:145-152

Main KL (1987) Predator avoidance in seagrass meadows: prey behavior, microhabitat selection, and cryptic coloration. Ecology 68:170-180

Mattila J, Heck KL Jr (2003) Does increased habitat structure provide increased refuge from predation? Gulf Mex Sci 21: 113

Mattila J, Heck KLJ, Millstein E, Miller E, Gustafsson C, Williams S, Byron D (2008) Increased habitat structure does not always provide increased refuge from predation. Mar Ecol Prog Ser 361:15-20

Minello TJ (1993) Chronographic tethering: a technique for measuring prey survival time and testing predation pressure in aquatic habitats. Mar Ecol Prog Ser 101:99-104

Nelson WG (1979) Experimental studies of selective predation on amphipods: consequences for amphipod distribution and abundance. J Exp Mar Biol Ecol 38:225-245
Nelson WG, Bonsdorff E (1990) Fish predation and habitat complexity: Are complexity thresholds real? J Exp Mar Biol Ecol 141:183-194

Orth RJ, van Montfrans J (1987) Utilization of a seagrass meadow and tidal marsh creek by blue crabs Callinectes sapidus. I. Seasonal and annual variations in abundance with emphasis on post-settlement juveniles. Mar Ecol Prog Ser 41:283-294

> Orth RJ, Heck KL Jr, van Montfrans J (1984) Faunal communities in seagrass beds: a review of the influence of plant structure and prey characteristics on predator-prey relationship. Estuaries 7:339-350

Pinckney JL, Micheli F (1998) Microalgae on seagrass mimics: Does epiphyte community structure differ from live seagrasses? J Exp Mar Biol Ecol 221:59-70

> Posey MH, Hines AH (1991) Complex predator-prey interactions within an estuarine benthic community. Ecology 72 : 2155-2169

Ryer CH (1988) Pipefish foraging: effects of fish size, prey size and altered habitat complexity. Mar Ecol Prog Ser 48:37-45

Savino JF, Stein RA (1982) Predator-prey interaction between largemouth bass and bluegills as influenced by simulated, submersed vegetation. Trans Am Fish Soc 111:255-266

Schneider FI, Mann KH (1991) Species specific relationships of invertebrates to vegetation in a seagrass bed. 2. Experiments on the importance of macrophyte shape, epiphyte cover and predation. J Exp Mar Biol Ecol 145:119-139

Sogard SM, Able KW (1994) Diel variation in immigration of fishes and decapod crustaceans to artificial seagrass habitat. Estuaries 17:622-630

Sogard SM, Olla BL (1993) The influence of predator presence on utilization of artificial seagrass habitats by juvenile walleye pollock, Theragra chalcogramma. Environ Biol Fishes 37:57-65

Spitzer PM, Mattila J, Heck KL Jr (2000) The effects of vegetation density on the relative growth rates of juvenile pinfish, Lagodon rhomboides (Linneaus), in Big Lagoon, Florida. J Exp Mar Biol Ecol 244:67-86

Stoner AW (1980) The role of seagrass biomass in the organization of benthic macrofaunal assemblages. Bull Mar Sci 30:537-551

Stoner AW (1982) The influence of benthic macrophytes on the foraging behavior of pinfish, Lagodon rhomboides (Linnaeus). J Exp Mar Biol Ecol 58:271-284

> Stoner AW (1983) Distributional ecology of amphipods and tanaidaceans associated with three sea grass species. J Crustac Biol 3:505-518

- Webster PJ, Rowden AA, Attrill MJ (1998) Effect of shoot density on the infaunal macro-invertebrate community within a Zostera marina seagrass bed. Estuar Coast Shelf Sci 47: 351-357

- Welsh BL (1975) The role of grass shrimp, Palaemonetes pugio, in a tidal marsh ecosystem. Ecology 56:513-530

Wilson KA, Able KW, Heck KL Jr (1990) Habitat use by juvenile blue crabs: a comparison among habitats in southern New Jersey. Bull Mar Sci 46:105-114

> Wyda JC, Deegan LA, Hughes JE, Weaver MJ (2002) The response of fishes to submerged aquatic vegetation complexity in two ecoregions of the mid-Atlantic bight: Buzzards Bay and Chesapeake Bay. Estuaries 25:86-100

Submitted: July 8, 2008; Accepted: August 13, 2009

Proofs received from author(s): October 21, 2009
Editorial responsibility: Thomas Minello,

Galveston, Texas, USA 